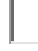

Buy Instant PDF Access

Qty:

$\$ 37.50$

- Cite Chapter

Available In

- Advances in Human Services and Public Health

- InfoSci-Books

- InfoSci-Media and Communications

- InfoSci-Medical, Healthcare, and Life Sciences

- InfoSci-Social Sciences and Humanities

- InfoSci-Select

- InfoSci-Social Sciences Knowledge Solutions - Books

\title{
A SWOT Analysis of Indigenous Language Use in Agricultural Radio Programming in Nigeria
}

Babatunde Adeyeye (Covenant University, Nigeria), Lanre Amodu (Covenant University, Nigeria), Odiboh Oscar (Covenant University, Nigeria), Oladokun Omojola (Covenant University, Nigeria), Evaristus Adesina (Covenant University, Nigeria) and Charity Amaka BenEnukora (Covenant University, Nigeria)

Source Title: Emerging Trends in Indigenous Language Media, Communication, Gender, and Health Copyright: (C) 2020 |Pages: 22

DOI: $10.4018 / 978-1-7998-2091-8 . \operatorname{ch} 010$

OnDemand PDF Download:

$\$ 37.50$

\section{Abstract}


This chapter investigates the strengths, weaknesses, opportunities, and threats of indigenous language use in agricultural radio programming in Nigeria within the theoretical frame of diffusion of innovations as well as the theory of planned behaviour. This discourse affirms existing assertions that using indigenous languages in agricultural radio programming can guarantee farmers' access to information on issues of agro materials, utility applications, support accessories, funding, technology, conservation, marketing, and pedagogy. The study concludes that indigenous language use in agricultural radio programming engages agricultural programme producers and farmers through their opinion leaders. It recommends that the use of indigenous languages in agricultural radio programming in Nigeria should continue. However, the country's agro policy should protect all farmers irrespective of cultural or ethnic divides; and specifically cater to the needs of minority ethnic groups of farmers.

Chapter Preview

$\underline{\text { Top }}$

\section{Introduction}

Access to agricultural information around the world allows farmers to make sensitive decisions leading to increased productivity in agriculture (Stefano, Hendriks, Stilwell, \& Morris, 2005; Wang et al., 2017; Khan, Aziz, \& Ahmed, 2018). In spite of this significance, Ozowa (1995) considers that the vital role that information plays in developing countries for agricultural and modern development is ignored and given a reduced status than other sectors of the economy. Alam and Haque (2014) support this perspective just as Wojcik, Jeziorska, Biel and Czapiewski (2019) who argue that a big part of rural regions still needs information and agricultural expertise to assist in modernizing their farming methods. Padre, Sundarshana and Tripp (2003) note that food production is reaching a point where unhindered information flow is becoming germane to stakeholders' achievements. Additionally, the adoption of Information Technology can significantly boost agricultural output (Waqas, Khan, Akhter, Noor, \& Ashraf, 2017; Ahmad et al., 2016).

Consequently, access to information has turned into an essential asset for agricultural development. In this unique situation, information is required to maximize openings and bring to limelight issues of present-day cultivation innovations. The Food and Agricultural Organization, FAO, (2006) states that sustained agricultural growth depends, at all phases of the agricultural production chain, on material input, human resources, farmers' comprehension and communication of data. Adeyeye et al., (2019) provide insight into the relationship between the use of new media for farmers ' training by extension workers and the rate of innovation by farmers. Agricultural expansion has been imagined with imparting research discoveries and enhanced agricultural practices, and the effectiveness with which this information and practices are passed on would decide the level of farmers' efficiency (Ani, 2001; Donye, 2018; Moyo \& Salawu, 2018). The most potent channel of this impartation are the media of mass communication (Odiboh, Salawu \& Doghudje, 2019; Odiboh \& Ekanem, 2019).

Among members of communication media, radio and its aired content are adduced the most ideal tool for achieving improved development of rural small-scale farmers in Africa (Ozowa, 2005). Additionally, advancements in information and communication technologies (ICTs) have made it fundamentally simpler and more reasonable to connect through and collaborate among audience 
members over the radio (Adeyeye et al., 2018). By utilizing new media technologies, it is conceivable to upgrade the potential of radio as a proficient circulation channel beyond mere expression. Radio programmes urge rural dwellers to take interest in development by embracing new innovations. Radio programmes empower groups to explain their encounters and basically look at issues and arrangements influencing their lives.

Communication in indigenous languages has been observed to enhance social harmony thereby encouraging African cultures to be preserved (Salawu, 2006). . According to Oyesomi and Salawu (2019), Indigenous language is a language that is spoken by a group of people that resides in a locality or region. Sonderling $(2009$, p. 85$)$ points out that language plays a main role in all fields of human endeavour because it is a conduit through which people interact. Such communication varies from circumstances of face to face to tactical mass mediation. Through the media, the use of indigenous languages to communicate with agrarian groups, particularly radio, provides the listener a feeling of belonging. Studies have shown that the use of native language in radio broadcasting is the best conduit of mass interaction as it achieves more easily than other media and is understood by the audience group (Mufwene, 2002; Manyozo, 2009). This constantly increases agricultural productivity in general terms.

\section{Key Terms in this Chapter}

Radio: The medium for transmitting electromagnetic signals through the atmosphere aimed at informing farmers about agricultural innovations.

Farmers: This refers to individuals engaged in agriculture and raising food crops in NorthCentral Nigeria.

Agriculture: This refers to the method by which certain crops are grown to produce food, feed, fiber and many other required products. There are two ways to see agriculture; traditional and modern. Traditional agriculture uses techniques developed over decades or centuries to ensure good, sustainable yield over time in a particular area or geopolitical area based on mixed crops complementing each other. On tiny family farms and in developing nations, traditional agricultural methods are most commonly practiced. Crops are mixed, often using the same crop's various varieties, and are sometimes planted in related communities. Modern agriculture, on the other hand, is an emerging approach to agricultural innovation and farming methods that helps farmers boost effectiveness and decrease the quantity of natural resources such as water, soil and power needed to satisfy the requirements of the world in terms of food, fuel and fiber.

Broadcasting: Head, Sterling, Schefield, Spinn and McGregor (1998 AU13: The in-text citation \&quot;Head, Sterling, Schefield, Spinn and McGregor (1998\&quot; is not in the reference list. Please correct the citation, add the reference to the list, or delete the citation. , p. 16) see broadcasting as the act of transmitting sound and images through radio waves to the general public through room for reception. This is the way to go in which broadcasting is used in this study.

Agricultural Communication: This includes all types of human communication related to farming, food, natural resources and rural concerns. 
Food Security: it is the situation in which all individuals have physical, social and financial access to adequate, secure and nutritious food at all times that meets their nutritional requirements and food preferences for active and healthy living. ( Porter et al. , 2014 ).

Radio Broadcasting: Radio broadcasting is the radio wave transmission aimed at reaching a broad audience. Therefore, stations are connected to broadcast a popular radio format in radio networks, either in broadcast syndication or simulcasting or both.

Farming: It is the act or method of soil cultivation, seed planting, and growing edible plants. It is also called, among other things, the process of raising cattle for milk or meat.

Agricultural Radio Programmes: This is used in this study to refer to the use of radio as a medium to exchange views from various sources by allowing Members of a specific group in order to obtain access to their data.

Innovation: refers an idea, exercise or object perceived as fresh in a social system by a person or group of individuals. Regardless of when the concept or exercise was initially created, it is an innovation for the individual when a individual first becomes conscious of it. An innovation may also be an improvement over the existing practice. Once such an improvement is new, it is regarded as an innovation.

Indigenous Languages: These are languages native to a country and spoken as a mother tongue by some of its indigenes. It also signifies people's knowledge culture and identity.

Abiodun Salawu

View Full PDF

Chapter 1

Indigenous Communication's Role in Traditional Birth Attendants in Maternal Health Practices:

A Selective Examination of Empirical Studies in Nigeria (pages 1-18)

Kehinde Opeyemi Oyesomi, Toluwanimi Onakoya, Kevin Onyenankeya, Ayobami Busari

Sample PDF

$\$ 37.50$

Chapter 2

Exploring the Use of Indigenous Languages in Antenatal Care Sessions Among Mothers in

Lagos State (pages 19-44)

Oludare Ebenezer Ogunyombo, Semiu Bello

Sample PDF

$\$ 37.50$

Chapter 3

Indigenous Communication and Traditional Health Practices Among the Yoruba During

Pregnancy, Child Delivery, and Baby Caring (pages 45-59)

Victor 'Tunji Taiwo

Sample PDF

$\$ 37.50$

Chapter 4

Indigenous Language Media and Safe Motherhood Practices (pages 60-77) 
Aloysius Chukwuebuka Ifeanyichukwu

Sample PDF

$\$ 37.50$

Chapter 5

Impact of Indigenous Language Media on Safe Motherhood Practices (pages 78-95)

Funmi Falobi

$\underline{\text { Sample PDF }}$

$\$ 37.50$

Chapter 6

Indigenous Language Media, Communication, and Sickle Cell Disorder: Peculiarities of

Indigenous Language Media in Tackling Misconceptions of Sickle Cell Disorder (pages 97-122)

Opeyemi Olaoluwa Oredola, Kehinde Opeyemi Oyesomi, Ada Sonia Peter

Sample PDF

$\$ 37.50$

Chapter 7

Indigenous Language Media and Communication for Health Purposes in the Digital Age (pages 123-145)

Toyosi Olugbenga Samson Owolabi, Nahimah Ajikanle Nurudeen

Sample PDF

$\$ 37.50$

Chapter 8

Potentials of Indigenous Media Campaign Against HIV/AIDS (pages 146-164)

Olayinka Susan Ogundoyin

Sample PDF

$\$ 37.50$

Chapter 9

Handling of Sexually Offensive Expressions on Zimbabwe's Selected Radio Stations (pages 166187)

Phillip Mpofu, Abiodun Salawu

Sample PDF

$\$ 37.50$

Chapter 10

A SWOT Analysis of Indigenous Language Use in Agricultural Radio Programming in Nigeria (pages 188-209)

Babatunde Adeyeye, Lanre Amodu, Odiboh Oscar, Oladokun Omojola, Evaristus Adesina, Charity Amaka Ben-Enukora

Sample PDF

$\$ 37.50$

Chapter 11

Global Media, Television, and the Americanization of Young Africans (pages 210-225)

Nelson Okorie

Sample PDF

$\$ 37.50$

Chapter 12

Health Education and Indigenous Language Media: Issues, Trends, and Perspectives (pages 227241) 
Olujoke Funmilayo Asekere, Olunike Rachael Asaolu

Sample PDF

$\$ 37.50$

Chapter 13

Corporate Communication, Indigenous Languages, and Community Relations: A Discourse on

Practices by Nigerian Universities (pages 242-262)

Thelma Ekanem, Rotimi Williams Olatunji, Lanre Amodu, Oscar Odiboh, Olusola Oyero

Sample PDF

$\$ 37.50$

Chapter 14

The Language Challenge of Diabetes Information and Education in Nigeria's Multi-Lingual

Setting (pages 263-275)

Chinyere Azuka Mbaka

Sample PDF

$\$ 37.50$

About the Contributors

Copyright (C) 1988-2020, IGI Global - All Rights Reserved 